\title{
Analisis Implementasi Program Perawatan Metode Kanguru (PMK) Dan Partisipasi Pasien Pada Pelayanan Kesehatan Bayi Berat Lahir Rendah (BBLR) (Studi pada Pasien di Rumah Sakit Mardi Rahayu Kudus)
}

\section{Implementation Analysis of the Kangaroo Mother Care (KMC) Program and Patients' Participation on the Service of Low Birth Weight (LBW) Babies (Study on Patients at Mardi Rahayu Hospital in Kudus)}

\author{
Nur Sri Atik ${ }^{1}$, Sri Achadi Nugraheni ${ }^{2}$, Kusyogo Cahyo ${ }^{2}$ \\ 1) AKBID Mardi Rahayu Kudus Jl. KH Wahid Hasyim No. 89 Kudus, No Telp (0291) 445979 \\ Email: hanansa_atik@yahoo.co.id \\ ${ }^{2)}$ Fakultas Kesehatan Masyarakat, Universitas Diponegoro, Semarang
}

\begin{abstract}
Abstrak
Perawatan Metode kanguru bisa sangat bervariasi di masing-masing rumah sakit, hal ini bisa dilihat dari aspek jenis layanan yang tersedia, kompetensi SDM, serta fasilitas dan sarana. Implementasi merupakan tahap yang krusial dalam proses kebijakan. Kesiapan serta keikutsertaan orangtua akan sangat mendukung dalam keberhasilan implementasi perawatan metode kanguru. Peran keluarga seperti sikap, perilaku dan partisipasi keluarga dipandang sebagai naluri untuk melindungi anggota keluarga yang sakit.

Tujuan penelitian ini adalah untuk mengetahui bagaimana proses implementasi dari faktor komunikasi, disposisi/sikap, sumber daya dan struktur birokrasi serta partisipasi pasien dan keluarganya dalam pelayanan kesehatan perawatan metode kanguru (PMK) di Rumah Sakit Mardi Rahayu.

Jenis penelitian ini adalah kualitatif dengan menggunakan wawancara mendalam dan observasi langsung dengan Informan utama adalah 4 orang ibu yang mempunyai BBLR dan informan triangulasi adalah 3 bidan dan 3 perawat, 2 dokter spesialis anak yang telah mengikuti pelatihan, serta manajer keperawatan dan direktur pelayanan medis. Analisis yang digunakan dengan analisis tematik, dimana mengolah data hasil wawancara mendalam sesuai tema yang ada.

Implementasi PMK menunjukkan hasil yang kurang optimal, dari sisi komunikasi terlihat belum adanya sosialisasi program sehingga terlihat kurangnya kejelasan, konsistensi dan transmisi informasi tentang program PMK. Dari sisi sikap/disposisi pelaksana menunjukkan kurangnya dukungan dari semua pelaksana dalam menjalankan program dan kurangnya komitmen. Dari faktor sumber daya diketahui adanya keterbatasan SDM terlatih, kurangnya sarana penunjang, dan belum adanya keberlanjutan anggaran untuk program. Faktor struktur birokrasi menunjukkan bahwa Standar operasional prosedur yang ada masih perlu direvisi dan belum adanya pembagian job yang jelas dalam PMK. Sementara partisipasi ibu belum begitu nampak baik dalam tahap pengambilan keputusan, pelaksanaan, pengambilan manfaat dan evaluasi. Hal ini disebabkan karena kurang optimalnya informasi yang diberikan. Saran bagi RS agar dapat meningkatkan sosialisasi program, serta penyampaian juklak dan pelaksanaan PMK diikuti dengan monitoring dan pembinaan. Selain itu meningkatkan komunikasi, informasi dan edukasi (KIE) bagi ibu/keluarga serta memberikan kesempatan bagi klien untuk melaksanakan PMK di RS sebelum pulang ke rumah.
\end{abstract}

Kata Kunci : Partisipasi pasien, Implementasi, Perawatan Metode Kanguru

Referensi : 13 (2003-2012) 


\section{Abstract}

Kangaroo Mother Care (KMC) varies in each hospital. This condition can be viewed from the aspects of types of services, competency of human resource, facilities, and means. Implementation is a crucial step in the process of policy. Readiness and participation of parents will support the success of the KMC implementation. A role of family such as attitude, behaviour, and family participation is as a desire to protect a family member who is sick.

This research aimed to identify the implementation process of factors of communication, disposition/attitude, resource, bureaucratic structure, and participation of patients and their families in KMC at Mardi Rahayu Hospital.

This was qualitative research using in-depth interview and direct observation. Main informants encompassed 4 mothers who had Low Birth Weight (LBW) Babies. Meanwhile, informants for triangulation purpose encompassed 3 trained midwives, 3 trained nurses, and 3 trained paediatricians, nursing manager, and director of medical services. Furthermore, data were analyzed using thematic analysis in which data as the result of in-depth interview were analyzed in accordance with a theme.

The implementation of KMC had not been done optimally. Regarding communication, there was no socialization of the program. Therefore, information of the KMC program was unclear, inconsistent. Regarding attitude/disposition of the program implementer, there was not only lack of support from all implementers in implementing the program but also lack of commitment. Regarding resource, there was lack of trained health workers, lack of facilities, and no sustainable fund for the program. Regarding bureaucratic structure, Standard Operating Procedure was needed to be revised and no clear job-sharing in KMC. Mothers had not participated in making decision, implementing, taking benefits, and evaluating yet. This was due to lack of information. As suggestions, the hospital needs to improve socialization of the program, provide implementation guidelines, and implement KMC followed by monitoring and supervising. In addition, the hospital needs to improve communication, information, education (CIE) for mother/family and provide opportunity for clients to implement KMC at the hospital before going home.

Keywords : Patient's Participation, Implementation, Kangaroo Mother Care

Bibliography : 13 (2003-2012)

\section{Pendahuluan}

Bentuk intervensi yang dilakukan dalam penanganan BBLR selama ini adalah berupa perawatan dengan inkubator. Penggunaan inkubator untuk merawat BBLR memerlukan biaya yang cukup tinggi atau relatif mahal. Negara-negara berkembang termasuk Indonesia akan dihadapkan pada masalah kekurangan tenaga terampil, biaya pemeliharaan alat, serta logistik. Akibat terbatasnya fasilitas inkubator, tidak jarang satu inkubator ditempati lebih dari satu bayi, sehingga dapat meningkatkan resiko terjadinya infeksi nosokomial di rumah sakit. Selain itu, penggunaan inkubator dinilai menghambat kontak dini ibu-bayi dan pemberian air susu ibu (ASI), serta berakibat ibu kurang percaya diri dan tidak terampil merawat bayi BBLR. ${ }^{1}$

Untuk mengatasi masalah diatas pada tahun 1983 dua ahli neonatologi dari Colombia menemukan perawatan metode kanguru (PMK) untuk mengatasinya. Metode kanguru mampu memenuhi kebutuhan asasi BBLR dengan menyediakan situasi dan kondisi yang mirip dengan rahim sehingga memberi peluang BBLR untuk beradaptasi dengan baik di dunia luar. Perawatan metode kanguru (PMK) atau Kangaroo Mother Care (KMC) telah terbukti mengurangi angka kematian, infeksi, meningkatkan pertumbuhan, tingkat menyusui, meningkatkan thermostasis dan meningkatkan ikatan ibu-bayi. Konsep perawatan metode kanguru ini telah diambil dan dimodifikasi agar dapat mengatasi perbedaan pengaturan kebutuhan baik di negara berkembang maupun di negara maju. ${ }^{1-3}$

Analisis terkini dari WHO menunjukkan bahwa sekitar 3 juta kematian BBLR dapat dicegah dengan cara memperbaiki akses atas intervensi yang tidak mahal, tepat guna (tidak 
teknologi tinggi) yang saat ini belum terjangkau oleh mereka yang memerlukan. Oleh karena itu dalam rangka menurunkan AKB karena BBLR, maka WHO telah menganjurkan untuk penerapan perawatan metode kanguru yang pelaksanaannya sangat mudah dilakukan oleh masyarakat asalkan memenuhi persyaratan. ${ }^{4}$

Perawatan metode kanguru merupakan salah satu cara perawatan BBLR yang lebih meningkatkan kontak batin ibu dan bayi dibandingkan dengan menggunakan inkubator yang membuat ibu dan bayinya terpisah. Ibu adalah orang yang paling dekat dengan bayi dan bertanggungjawab dalam merawat bayi. Oleh karena itu pengetahuan dan sikap ibu tentang perawatan BBLR secara tidak langsung dapat meningkatkan kesehatan BBLR. Kesiapan serta keikutsertaan orangtua akan sangat mendukung dalam keberhasilan perawatan metode kanguru. ${ }^{5}$ Peran keluarga seperti sikap, perilaku dan partisipasi keluarga dipandang sebagai naluri untuk melindungi anggota keluarga yang sakit, dengan demikian peran serta keluarga sangat penting bagi setiap aspek perawatan kesehatan anggota keluarga mulai dari segi strategi pencegahan sampai fase rehabilitasi. ${ }^{6}$ Metode PMK ini kemudian diadaptasi dalam program Rumah Sakit Sayang Ibu dan Bayi (RSSIB) menjadi salah satu dari 10 langkah perlindungan ibu dan bayi secara terpadu dan paripurna.

Rumah sakit sebagai institusi yang melakukan upaya rujukan harus mampu mengelola BBLR termasuk didalamnya PMK. Kementrian Kesehatan bersama dengan organisasi profesi mengembangkan metode ini melalui kegiatan untuk membangun jejaring pelayanan dari tingkat pelayanan dasar sebagai bagian dari program PONED (Pelayanan Obstetri Neonatal Emergency Dasar) sampai tingkat pelayanan rujukan di RS sebagai bagian dari program RSSIB dan PONEK. ${ }^{1}$

Dalam pengelolaannya perawatan metode kanguru bisa sangat bervariasi di masingmasing rumah sakit. Hal ini bisa dilihat dari aspek jenis layanan yang tersedia, kompetensi SDM (sumber daya manusia), serta fasilitas dan sarana yang ada. Berdasarkan pedoman pelayanan kesehatan BBLR dengan PMK di RS dan jejaringnya, pengelolaan PMK di RS dikoordinir oleh tim pokja (Kelompok Kerja) perinatal yang ditetapkan dengan SK Direktur, secara prinsip layanan PMK menjadi bagian dari pelayanan anak/perinatal. ${ }^{1}$

Berdasarkan hasil studi pendahuluan diketahui bahwa angka kejadian BBLR di Rumah Sakit Mardi Rahayu cukup tinggi dan merupakan salah satu dari 5 besar penyakit di RS. Dari data yang ada diketahui angka kejadian BBLR pada tahun 2011-2013 berkisar antara 11,7\%-13,3\% dari jumlah kelahiran, sedangkan jumlah kematian neonatal karena BBLR di RS Mardi Rahayu sejak tahun 2011 sampai tahun 2013 berturutturut sebayak 52,1\% (37 dari 71), 43,4\% (20 dari 46) dan 55,5\% (35 dari 63). Hasil studi pendahuluan menunjukkan bahwa RS Mardi Rahayu belum bisa melaksanakan perawatan metode kanguru secara optimal. Hal ini dilatarbelakangi karena kurangnya sarana pendukung berupa ruangan tempat pelayanan, belum banyak tenaga yang pernah mengikuti pelatihan tentang PMK, sementara pendidikan kesehatan tentang informasi PMK disampaikan pada pasien dan keluarga saat pasien mau pulang agar dapat dilaksanakan di rumah. Selain itu juga disampaikan dari perawat bahwa hal ini juga disebabkan kurangnya kemauan ibu atau orang tua bayi untuk melakukan PMK karena merasa takut dengan bayi yang masih kecil sehingga membuat ibu maupun keluarga merasa kurang berani untuk mendekati bayinya. Dari informasi kepala ruang perinatologi juga didapatkan data bahwa angka perawatan BBLR di RS Mardi Rahayu cukup lama dengan waktu rentang hampir 1 bulan dan rata-rata tidak mencapai lama waktu perawatan yang disarankan karena keterbatasan biaya perawatan sehingga banyak pasien yang akhirnya pulang atas permintaan sendiri.

Perumusan masalah dalam penelitian ini adalah belum optimalnya implementasi program PMK di RS Mardi Rahayu. Kuranganya sarana pendukung seperti tempat, SOP yang disusun kurang optimal serta kurangnya informasi yang diberikan kepada pasien sehingga pasien dan keluarga kurang berani untuk melakukan perawatan metode kanguru, selain itu minimnya tenaga kesehatan yang telah mendapatkan pelatihan tentang 
PMK juga menjadi salah satu kendala dalam pelaksanaannya.

Berdasarkan konsep dan kerangka pemikiran diatas, muncul beberapa pertanyaan sebagai dasar dan bahan untuk menganalisis pelaksanaan program perawatan metode kanguru (PMK). Adapun pertanyaan penelitian tersebut yaitu: Bagaimana implementasi program Perawatan Metode Kanguru (PMK), bagaimana proses komunikasi, sumber daya, disposisi dan struktur birokrasi serta bagaimana partisipasi ibu dan keluarga dalam memberikan pelayanan kesehatan dengan perawatan metode kanguru pada bayi BBLR di Rumah Sakit Mardi Rahayu Kudus?

\section{Metode Penelitian}

Jenis penelitian yang digunakan adalah penelitian deskriptif kualitatif untuk menganalisis partisipasi pasien dan implementasi program perawatan metode kanguru pada pelayanan kesehatan bayi berat lahir rendah (BBLR) dan permasalahannya di Rumah Sakit Mardi Rahayu Kudus. Penelitian dilaksanakan di RS Mardi Rahayu Kudus yang merupakan salah satu RS swasta klasifikasi strata B, akreditasi penuh tingkat lengkap ke 2 dengan 16 bidang pelayanan. Salah satu bidang pelayanannya adalah pelayanan kesehatan ibu dan anak.

Informan utama penelitian adalah 4 orang ibu dari pasien dengan BBLR yang di rawat di
RS Mardi Rahayu Kudus. Informan triangulasi dalam penelitian ini adalah 3 orang perawat ruang perinatologi, 3 orang bidan kamar bayi, 2 orang dokter spesialis anak yang memberi pelayanan pada BBLR, manajer keperawatan RS dan direktur pelayanan medis dan keperawatan.

Data yang diambil dalam penelitian ini adalah data primer melalui wawancara mendalam dan data sekunder melalui telaah dokumen. Setelah pengumpulan data selesai dilaksanakan maka data dianalisis menggunakan metode analisis tematik, yaitu pengumpulan data, reduksi data dan pembuatan outline data berdasarkan tema yang ada, penyajian data dan kesimpulan.

\section{Hasil}

Berdasarkan hasil observasi dan wawancara mendalam dari beberapa informan utama dan informan triangulasi dapat diketahui bahwa pelaksanaan atau implementasi program PMK belum berjalan dengan maksimal. Pelaksanaan program ini hanya sebatas pemberian informasi dalam bentuk pendidikan kesehatan yang diberikan kepada pasien menjelang pasien pulang. Untuk pelaksanaan program perawatan metode kanguru baik yang intermitten maupun yang continue belum bisa dilaksanakan secara optimal. Hal ini sesuai dengan kutipan pada kotak berikut ini :

Kotak 1: Pelaksanaan PMK

(geleng kepala) belum semuanya bisa, (IT1;42)

Kayaknya kok belum optimal ya, tapi maksudnya secara ini khusus gini kok kayaknya belum, paling cuma informasi saja (IT2;44)

......jadi hanya sebatas pengetahuan, yang diberikan ke pasien juga hanya penkes aja mbak, ya sedikit lah (IT3;39)

Terus terang ya mbk, khususnya saya sendiri ya ndak pernah ya mbk. Mungkin bu Kurnia itu yang sudah mempraktekan.(IT4;34)

Sudah tapi jarang mbak......... (IT5;38)

Sampai sejauh ini pelaksanaan yang diberikan belum maksimal (IT6;33)

..... Sampai sekarang hanya sebatas pemberian informasi, .... (IT7;27)

Belum semua mbk, masih belum optimal..... (IT8:28)

Ya memang kita ini belum sepenuhnya ya mbak, baru tahap melaksanakan jadi ya belum optimal. (IT9;43)

Ya kalau dikita artinya dikita sudah ada cuma tapi belum semuanya, (IT10;48)

Komunikasi dalam pelaksanaan program dapat diketahui dari proses sosialisasi program sehingga dapat menunjukkan bagaimana kejelasan informasinya, konsistensi dan bagaimana transmisi dari program PMK tersebut. Dari hasil wawancara mendalam diketahui bahwa sebagian besar informan menyatakan sosialisasi program belum 
dilakukan baik dari manajemen/divisi perawatan maupun dari kepala ruang ke bidan atau perawat pelaksana. Dengan demikian belum ada kejelasan informasi yang didapatkan dari sosialiasi yang seharusnya dilakukan oleh penyelenggara program. Hal tersebut dapat diketahui dari kutipan sebagai berikut :

Kotak 2: Sosialisasi Program PMK

Nggak, saya si selama disini belum pernah ya, gak tau juga kalo yang lain bagaimana $($ IT1;42)

Saya si belum pernah dapat sosialisasi disini, atau saya lupa ya mbak, (IT2;44)

Belum, karena memang program baru kendalanya belum ada yang ikut pelatihan. Jadi memang mau melaksanakan itu setangah setengah. (IT3;39)

Ndak ada kalau diperistri sendiri, ndak tahu ya kalau di eva, kalau diperistri belum pernah. Kadang mbk Nia kasih tau sih ya kalau buat bayi BBLR PMK itu sangat dibutuhkan sangat penting gitu thok........ (IT4;34)

Kok kayake belum ada ya mbak, apa saya yang gak tau ya mbak, tapi biasane kalau ada apa-apa disampaikan waktuya di rapat ruangan setiap bulannya. (IT5;38)

Saat itu memang kebetulan saya yang dikirim untuk mengikuti sosialisasi tentang perawatan metode kanguru di Jogja, sudah saya sosialisasikan semua ke direktur maupun ke ruangan (IT6;33)

Belum ada, kayake kok belum pernah ada ya, bener gak dek hehe.... dulu dapat info waktu kuliah di AKBID dulu, hehe sekitar 6 tahun yang lalu,.... (IT7;27)

Sudah apa belum ya mbak? mungkin karena aku tidak terlalu turun ke lapangan, jadi aku pikir sudah disosialisasikan dilapangan. mungkin saya kurang komunikasi. harusnya tidak menjadi masalah ya, walau yang dilatih cuma satu orang, seharusnya dia tetap sosialisasi, (IT10;48)

Disposisi adalah watak dan karakteristik yang dimiliki oleh implementator (pelaksana) seperti komitmen, kejujuran, dan inisiatif yang dimiliki. Berdasarkan hasil wawancara mendalam diketahui bahwa sebagaian besar informan setuju dengan adanya program PMK, karena itu memang diperlukan bagi BBLR, mengingat kejadian BBLR masuk 5 besar penyakit di RS Mardi Rahayu. Dukungan terhadap program belum begitu terlihat terutama dari manajemen sehingga peran yang dilakukan masih terbatas, hal ini karena dari penyelenggara program sendiri belum memahami secara keseluruhan tentang program tersebut yang disebabkan oleh terbatasnya informasi yang didapat, kejelasan informasi serta petunjuk yang diperlukan untuk mengimplementasikan program. Hal tersebut dapat diketahui dari kutipan berikut ini :

\section{Kotak 3: Dukungan Terhadap PMK}

Nah itu, kayaknya kok belum sepenuhnya ya, ya kata yang dulu-dulu si kalo dibagian anak gak begitu diperhatikan gitu,...... (IT1;44)

Kayaknya memang dari RS sendiri itu belum ngeh ya, yang dipikir masih yang real, nyata seperti alat-alat yang besar, sementara untuk hal seperti itu kayake belum terlalu diperhatikan. (IT2;44)

Kalau dari dokter Sp.A mendukung sekali, yang baru termotivasi itu dr Martin, ikut berperan. Kalau dari manajemen?Kalau sudah bagian dari program mestinya ya mendukung (IT4;39)

Ya semua mendukung mbak, cuma prakteknya memang belum semua,..... (IT5;38)

Kalau dari dokter selama ini yang diketahui belum ada advice dari dokter untuk melakukan PMK akan tetapi kalau untuk menjaga kehangatan memang itu secara tidak langsung sudah masuk dalam askeb kami. (IT6;33)

....Juga ngikuti aturan atasan hehe..... (seandainya aturan itu dilaksanakan?) ya berarti kan ada tenaga kesehatan yang harus ditambahkan, hehe ya iyalah bu..... (IT7;27)

Peran, ya selama ini kalau dari ruangan ada yang minta kebutuhan seperti baju kanguru atau yang lain kemarin si ya saya acc mbak. (IT9;43)

Mungkin ini harus bisa dihidupi lagi sembari persiapan2 apa yang dibutuhkan kita, taruhlah misalnya tidak semua tempat tidur yang kita kasih registering, tapi misalnya beberapa. (IT10;48) 
Dari kutipan diatas diketahui bahwa pelaksana seperti perawat dan bidan serta dokter spesialis anak sendiri mendukung program tersebut, akan tetapi perlu dukungan juga dari manajemen sebagai pengambil kebijakan. Apabila program yang diajukan sudah disetujui tentunya diimbangi dengan dukungan terhadap semua kebutuhan yang diperlukan sehingga mengurangi kendala dalam mengimplementasikan program. Beberapa kendala yang muncul adalah sebagai berikut :

Kotak 4: Kendala yang ada dan sikap dalam menghadapi kendala

.... RS nya sendiri ya gimana ya, kayaknya ya nggak begitu....untuk tempat aja nggak ada tempat khusus hanya pojok ASI itu yang bisa dipakai $($ IT1;42)

Kalau saya ya hanya saya jelaskan saja untuk menjaga kehangatan pada bayinya, karena bayi kecil kan resiko hipotermi, tapi memang kadang itu ibunya gak ada ya. (IT2;44)

Yang dilakukan apa bu? Memberikan edukasi terutama pada ibu, istilahnya setelah melahirkan itu bagi ibu suatu hal yang sangat berat/ resiko untuk datang ke RS (IT3;39)

Seringnya ya itu tadi belum tutuk perawatannya disini sudah minta pulang paksa.... itu kecil kecil juga ini yang kecil juga sudah minta pulang mungkin belum bisa minum karena kaitannya biaya sekali lagi biaya.. (IT4;34)

Sebenarnya baik, tapi memeng kita masih terkendala dengan sarana dan tenaga. Saya setuju dengan adanya PMK karena itu memang diperlukan oleh bayi (IT6;33)

Programnya itu baik sebenarnya, tapi untuk melaksanakannya itu yang kendalanya juga masih lumayan. (IT7;27)

Kendalanya paling ibu ketakutan bayinya jatuh kendalanya dalam memberikan penkes ya biasa aja, paling kita ngomong caranya gini gini , memotivasi mamanya, meyakinkan keluarga untuk bisa melakukan itu, yang dilakukan kita memberikan penjelasan lebih detail lagi. (IT8;28)

Sumber daya dalam implementasi hasil obervasi dan wawancara mendalam yang program perawatan metode kanguru di rumah dilakukan, diketahui bahwa sebagian besar sakit dapat meliputi sumber daya manusia, informan menyatakan jumlah tenaga yang ada sumber dana atau anggaran dan sumber daya dalam memberikan pelayanan belum yang berbentuk sarana prasarana pendukung mencukupi kebutuhan, hal tersebut dapat program seperti ruangan, peralatan pendukung seperti alat, dan media informasi. Berdasarkan dilihat dalam kutipan sebagai berikut :

Kotak 5: Kecukupan Pelaksana Program

Kalau pas pasiennya sedikit ya gak apa-apa si mbak, tapi kalo pas pasiennya banyak kayake kok perlu ya, ..... Padahal pasien BBLR kan juga banyak banget disini (IT1;42)

Kalau pasien banyak terus terang tenaga kewalahan, karena kalo yang dikamar bayi itu hanya 2, di peristi ada 2-3 orang ..... Kalau untuk PMK mungkin harus ditambah karena perlu ada pengawasan tentunya. (IT2;44)

Perlu tambahan, disini ada 15 standartnya 17, bed ada 15" (IT3;39)

Jika dilakukan ya perlu penambahan tenaga, jumlah perawat 15 dengan kapasitas 10 tapi seringnya lebih dari itu.(IT5;38)

"Saya rasa belum mencukupi ya mbak, karena kalau pelaksanaan PMK itu kan perlu pengawasan khusus secara terus menerus sementara tenaga kita cuma beberapa dengan job yang bermacammacam.......Di ruang bayi ada 2 bidan 1 bidan melengkapi administasi dan dokumentasi, 1 bidan sebagai pelaksana untuk BBL. Contoh saja kalau bayi 17 pasien pulang 10, masih ada rawat gabung, ada bimbingan juga tenaganya gak memungkinkan. (IT6;33)

Struktur birokrasi berkenaan dengan Struktur birokrasi yang bertugas kesesuaian organisasi birokrasi yang menjadi mengimplementasikan kebijakan memiliki penyelenggara implementasi kebijakan. pengaruh yang sangat signifikan terhadap 
implementasi. Aspek struktur birokrasi menyangkut dua hal penting yaitu mekanisme dan struktur organisasi pelaksana sendiri. Struktur birokrasi dalam hal ini berkaitan dengan ketersediaan surat keputusan (SK) dan SOP. Berdasarkan hasil observasi dan wawancara mendalam diketahui bahwa dokumen SK dan SOP sudah ada akan tetapi dalam waktu terakhir ini masih harus diperbaiki kembali sesuai dengan ketentuan untuk persiapan akreditasi RS. Hal itulah yang menjadi salah satu alasan belum disosialisasikannya SOP itu kepada seluruh pelaksana program, walaupun secara resmi sudah ada ketentuan bahwa program tersebut harus dilaksanakan berdasarkan SK yang ada. Hal tersebut dapat diketahui dari kutipan sebagai berikut :

Kotak 6: Keberadaan SK maupun SOP

"Kayaknya kok gak ada ya, tapi ...... saya kok lupa ya, tapi sepertinya bu nia pernah minta tolong saya untuk lihat beberapa SOP tapi sudah ada PMK belum ya, tapi sepertinya kok sudah ada ya." $(\mathrm{IT} 1 ; 44)$

"Sudah ada, tapi ini baru range-range'an lagi karena mau akreditasi. yang menyusun saya sendiri." (IT3;39)

"kalau saya sendiri SK nya ya itu mbak belum tahu ..... Jadinya kalau memang tahu ya sich seharusnya tapi secara operasional prosedurnya step by stepnya seperti apa itu yang belum tahu, dan juga belum disosialisasi juga" (IT4;34)

"Belum ada mbak, SOP dibuat dari manajemen sana mbk, dari penduwuran (IT5;38)

"SOP kami ada tapi ini masih harus direvisi lagi karena mau ada akreditasi, jadi yang ini belum ditanda tangani direktur. SOP yang ini belum disosialisasikan ke pelaksana karena karena belum acc direktur." (IT6;33)

"SOP belum ada, belum lihat juga. Apa memang tidak lihat ya mbk. Karena belum disosialisasikan juga. (IT7;27)

SOP kayake saya belum pernah lihat, tapi biasanya yang nyusun bu erna mbak. (IT8;28)

Bu nia sepertinya sudah pernah disusun tapi memang kendalanya ini karena mau akreditasi jadi harus disesuaikan lagi dengan yang diminta akreditasi.(IT9;43)

SOP ada apa gak ya mbak nanik? Kayake ya ada mbak. (IT10;48)

Partisipasi ibu dan keluarga dalam keluarga untuk dapat melakukan perawatan pelaksanaan PMK merupakan salah satu berkelanjutan di rumah setelah keluar dari bagian dari keberhasilan implementasi RS.Dari hasil observasi dan wawancara program PMK. Adanya program ini mendalam dapat diketahui hasilnya : diharapkan dapat melatih ibu dan atau

Kotak 7: Peran dan kesediaan ibu dalam PMK

Ya bersedia (IU1;37)

Ya bersedia, (berapa lama melakukan?) 1 kali saja waktu dirumah. (IU2;35)

Ya, ya gimana ya, ya bersedia si yo piye yo kan belum tahu juga, kalau bisa si saya praktekan, tapi kan belum tahu juga. (IU3;35)

Ndak tau, belum dicoba, baru pertama ini (IU4;39)

Ya itu tadi mbak, pasien nya itu anu banget kalau SC, yang sakit lah yang gimana lah yang kayaknya itu belum mau pegang anaknya. (bagaimana kalau pasien yang tidak sc dok?) ya kalau nggak SC ibunya pulang dan yang sering datang untuk berkunjung itu mbahnya, bapaknya si ibunya juga jarang datang. (IT1;42)

Kalau ditanya bersedia ya jawabannya nanti tak ngomong-ngomong dulu dengan suami dan dengan keluarga, karena rata-rata sosial ekonomi memang kurang mbak, jadi tidak bisa putuskan sendiri, butuh dukungan orang-orang yang terdekat (IT6;33)

Kadang ada yang antusias, Kadang ada beberapa yang cuek dan tidak peduli. Untuk mendalami lebih detail butuh waktu tidak hanya 1 atau 2 hari.... (IT7;27)

Kalau ibu ya berperan si mbak, tapi memang disini kadang yang datang ambil bayinya itu justru malah mbahnya, budenya, ibunya itu terlalu ini banget si mbak, kayak gimana ya. Kalo SC ya 
Kendala-kendala dalam partisipasi yang dihadapi oleh ibu dan atau keluarga dapat diketahui dari kotak berikut ini :

Kotak 8: Kendala-Kendala dalam partisipasi

Kendalanya kalo ibu sudah pulang, kan kalo belum selapan kan ndak boleh keluar keluar. Sosial budaya mungkin ya.(IT4;34)

Bayi yang kecil itu kan digedhong, terus gak boleh di kangkangke, harus digubet-gubet. Kalau diposisikan begitu (diperagakan tidak boleh kalau ditaruh didada, sebaiknya ditempatkan diposisi tangan) katanya takut kalau klenggak, itu menurut beberapa orang bu, tidak boleh mekeh, kan gak boleh to kalo orang tua-tua, kan masih belum bisa nyangga kepalanya sendiri. $(\mathrm{IT7} ; 27)$

kalau dari ibunya kadang adat yang bilang orang jawa kalau anak belum 1 tahun kan gak boleh dipekeh itu lo mbak, jadi ya kadang bilange kok aneh ya.(IT8;28)

Ya mungkin tidak umum begitu, karena udo. mungkin kalau kayak gini gini mungkin orang barat cuek saja, walaupun kita sebenarnya ndak papa, mungkin ada perasaan lucu ya, mungkin belum membudaya (IT10;48)

Ya repot bu, kalo sendirian di rumah gak bisa (IU2;35)

lha kasian gitu lo bu, diengkak engkuk dimasukan dalam situ, digendong dalam baju kanguru, jadi kayak gimana ya bu, kayake kok menyiksa bayinya, Ya repot bu, kalo sendirian di rumah gak bisa. Ya aktifitasnya terganggu itu ah, cara mengatasinya ya itu tadi bayinya ditidurkan (IU3;35)

Ya rumit aja, Gak pernah mbak, tidak bisa praktek. Kan kerjane di pabrik mbak, nek diomong orang kok aneh-aneh iku opo.(IU4;39)

\section{Pembahasan}

Implementasi program perawatan metode kanguru di rumah sakit dapat dibagi dalam beberapa kategori, salah satu kategorinya adalah apabila RS memiliki tenaga dan fasilitas yang memadai maka PMK bermanfaat untuk meningkatkan ikatan antara ibu dan bayi, mengurangi risiko infeksi, meningkatkan ASI dan mempersingkat lama perawatan di rumah sakit. ${ }^{7}$ Dalam implementasinya perawatan metode kanguru meliputi 4 komponen yaitu komponen posisi kanguru, komponen pemberian nutrisi, komponen dukungan/support dan komponen pemulangan pasien serta mengkaji pelaksanaan pada pasien BBLR paska perawatan di rumah sakit. ${ }^{1}$

Dari 4 komponen yang ada dalam PMK, RS Mardi Rahayu secara keseluruhan belum dapat mengimplementasikan secara maksimal. Komponen yang telah dilakukan adalah komponen pemberian support khususnya dukungan edukasi yang sebagian besar informan menyatakan bahwa belum ada jadwal khusus untuk PMK, pemberian informasi PMK dilakukan beberapa menit sebelum bayi pulang. Kurang maksimalnya implementasi program PMK yang dilakukan berkaitan dengan beberapa faktor yang ada, sesuai dengan toeri G. Edward III beberapa faktor yang melatar belakangi keberhasilan implementasi program adalah adanya komunikasi, sumber daya, disposisi/sikap pelaksana, dan struktur birokrasinya.

Faktor komunikasi dalam implementasi PMK diketahui belum ada sosialiasasi yang dilakukan di RS Mardi Rahayu. Hal ini terjadi karena kurangnya monitoring dari pembuat kebijakan sendiri dan kurangnya pemantauan langsung pada program, sehingga kurang mengetahui juga bagaimana proses sosialisasi berlangsung. Sementara dari tenaga yang diutus untuk mengikuti sosialisasi program sudah mensosialisasikan hal tersebut akan tetapi belum merata untuk semua pelaksana, dan hal itu belum ditindak lanjuti kembali karena waktu sosilisasi sudah sangat lama. Dalam hal kejelasan informasi yang didapatkan juga diketahui bahwa sebagian besar pelaksana menyatakan belum jelas terkait dengan pelaksanaan program karena belum ada sosialisasi. Sebagian besar yang telah mendapat informasi juga menyatakan kalau informasi yang diberikan tentunya bisa 
dimengerti oleh pasien. Sedangkan dari sisi pasien menyatakan bahwa informasi yang diterimanya masih kurang begitu jelas sehingga pasien kurang bisa memahami maksud dari program tersebut. Kurang jelasnya informasi ini karena waktu penyampaian informasi yang pendek, pasien yang akan pulang diberikan pendidikan kesehatan sementara sebelumnya belum pernah mendengar tentang program PMK.

Agar implementasi kebijakan berjalan efektif, perintah pelaksanaan harus diberikan secara konsisten dan jelas. Perintah-perintah implementasi yang tidak konsisten akan mendorong para pelaksana mengambil tindakan yang sangat longgar dalam menafsirkan dan mengimplementasikan kebijakan. Akibatnya terjadi ketidakefektifan implementasi karena tindakan yang sangat longgar dan besar kemungkinan tidak tepat dalam pelaksanaan tujuan. ${ }^{8}$ Dari hasil analisis yang dilakukan dapat diketahui juga bahwa kegiatan sharing untuk menyelesaikan masalah dengan pelaksana lain atau dengan pasien juga belum dilakukan dalam PMK sekalipun untuk kegiatan yang lain sudah dilakukan dalam rapat rutin atau bulanan di masing-masing ruangan. Sikap para pelaksana akan menimbulkan hambatan yang nyata terhadap implementasi, dengan demikian perlu pemilihan dan pengangkatan personil yang memiliki dedikasi. Selain itu salah satu teknik yang disarankan untuk mengatasi masalah kecenderungan para pelaksana adalah dengan memberikan insentif.

Dari hasil analisis diketahui juga bahwa implementasi yang belum optimal bisa terjadi karena jumlah tenaga yang telah mengikuti pelatihan PMK juga terbatas. Kekurangan staf yang terampil merupakan masalah utama dalam program-program baru yang membutuhkan keahlian. Ruang lingkup dalam staf ini meliputi tingkat pendidikan, tingkat pemahaman terhadap tujuan, dan kemampuan menyampaikan program dan mengarahkan. ${ }^{10,11}$ Terbatasnya fasilitas dan peralatan dalam pelaksanaan kebijakan menyebabkan kegagalan implementasi. Hal ini dikarenakan dengan terbatasnya fasilitas apalagi yang sudah usang, terutama ketertinggalan dalam teknologi informasi sulit untuk mendapatkan informasi yang akurat, tepat, handal dan dapat dipercaya sehingga akan merugikan pelaksanaan akuntabilitas. Terbatasnya fasilitas yang tersedia menyebabkan tidak efisien implementasi dan dapat menurunkan motivasi para pelaksana dalam implementasi kebijakan. ${ }^{12}$

Faktor struktur birokrasi yang juga mempengaruhi kurang optimalnya implementasi PMK adalalah SOP. Keberadaan SOP akan mempengaruhi pelaksanaan program, kurang jelasnya SOP baik menyangkut mekanisme, sistem dan prosedur pelaksanaan kebijakan, pembagian tugas pokok, fungsi, wewenang dan tanggung jawab diantara para pelaku dan tidak harmonisnya hubungan diantara organisasi pelaksana satu dengan yang lain ikut menentukan gagalnya pelaksanaan suatu kebijakan. $^{2}$

Dalam kasus ini terlihat belum nampak adanya partisipasi pasien dalam implementasi program PMK, hal ini dapat juga bisa terjadi karena penyelenggara program yaitu pihak pelaksana di RS juga belum memberikan pelayanan sesuai dengan standarnya, komponen PMK yang dilaksanakan hanya ada pada komponen dukungan informasi, sementara mereka tidak mendapat kesempatan untuk mencoba sebelumnya di RS, dengan demikian saat harus mempraktekan di rumah ibu maupun keluarga juga belum mampu, dan belum yakin bisa melakukan, ditambah dengan adanya kendala yang ada, waktu yang tersita, kerepotan yang dialami dirumah apabila tidak ada dukungan keluarga. Selain itu, faktor budaya dan adat yang belum familiar dengan adanya PMK, begitu juga lingkungan sekeliling ibu dan atau keluarga yang juga belum banyak mengenal hal ini menjadi kendala tersendiri untuk ibu dan keluarga. Faktor lain lagi yang juga perlu diperhatikan adalah tingkat pendidikan ibu yang kurang sehingga menyebabkan pemahaman yang kurang yang pada akhirnya informasi tidak bisa tersampaikan dengan baik.

Beberapa faktor yang mempengaruhi sikap ibu dan atau keluarga yaitu pengalaman pribadi, kebudayaan, orang lain yang dianggap penting, media massa, institusi atau lembaga pendidikan dan lembaga agama, serta faktor emosi dalam diri individu. Pengalaman pribadi merupakan salah satu dasar terbentuknya 
sikap, seseorang harus mempunyai pengalaman yang berkaitan dengan objek psikologis. Selain pengalaman orang lain disekitar kita merupakan salah satu diantara komponen sosial yang ikut mempengaruhi sikap kita. Diantara orang yang biasa dianggap penting bagi individu adalah orang tua, orang yang status sosialnya lebih tinggi, teman sebaya, teman dekat, guru, teman kerja, istri atau suami, dan lain-lain. Pelaksanaan PMK dapat terlaksana dengan adanya dukungan dari keluarga. Selain adanya dukungan, PMK juga dapat terlaksana apabila ibu sudah memahaminya dan melaksanakannya atas keputusan sendiri. ${ }^{13}$

\section{Kesimpulan}

Dengan demikian secara keseluruhan dapat diketahui bahwa implementasi program perawatan metode kanguru di RS Mardi Rahayu Kudus belum berjalan dengan optimal. Hal ini disebabkan dari faktor penyelenggara program sendiri belum melakukan sosilisasi program PMK sebagai bentuk komunikasi yang harus disampaikan sehingga dapat terlihat bahwa belum ada kejelasan, konsistensi maupun transmisi informasi tentang PMK. Hal ini juga dilatar belakangi karena sumber daya yang diperlukan khususnya SDM terlatih yang mempunyai pengetahuan dan keterampilan tentang PMK belum banyak. Kurangnya kompetensi ini juga yang berakibat pada kurang maksimalnya SOP yang telah disusun sehingga harus disesuaikan dan direvisi kembali. Dari hal ini akhirnya membawa pengaruh juga terhadap sikap pelaksana program yang kurang mendukung sepenuhnya program PMK ini karena belum adanya sosilisasi SOP maupun konsistensi perintah dan informasi.

Sikap dan komitmen ini tentunya juga perlu dimiliki oleh penyelenggara program dalam hal ini adalah pihak manajemen RS sebagai pengambil kebijakan program. Apabila program diawali dengan komitmen yang tinggi, maka akan dapat menunjang keberhasilan program. Komitmen ini tentunya dapat ditunjukkan dengan adanya monitoring dan evaluasi dalam implementasi program sehingga dapat memantau keberlanjutan dan kendala yang ada dalam program
tersebut.Sementara dari sisi sasaran program terlihat belum adanya juga partisipasi aktif dalam implementasi program. Hal ini terjadi karena kurangnya informasi yang diberikan oleh petugas kesehatan sehingga pasien kurang memahami tentang program yang dijalankan, selain itu juga belum adanya kesempatan untuk melakukan PMK secara langsung di RS. Faktor lain yang juga mempengaruhi adalah lingkungan keluarga maupun adat istiadat, pengalaman dan pendidikan ibu dan keluarga yang kurang sehingga mengurangi kemampuan ibu maupun keluarga untuk dapat berpartisipasi dalam PMK.

\section{DAFTAR PUSTAKA}

1. Direktorat Jenderal Bina Pelayanan Medik Depertemen Kesehatan RI. Pedoman Pelayanan Kesehatan Bayi Berat lahir rendah (BBLR) dengan Perawatan Metode Kanguru di Rumah Sakit dan jejaringnya. Jakarta: Departemen Kesehatan RI; 2009.

2. Bailey, SD. Kangaroo Mother Care. British Journal of Hospital Medicine. May 2012; vol 73; no.5; 278-81.

3. Direktorat Jenderal Bina Pelayanan Medik Departemen Kesehatan RI. Pedoman Pelaksanaan Program Rumah Sakit Sayang Ibu dan Bayi. Jakarta: Departemen Kesehatan RI; 2009.

4. Departemen of Reproductive Health and Research. Kangaroo Mother Care a Practical Guide. Geneva: WHO; 2003.

5. Rahmayanti, Siti Dewi. Pengaruh Perawatan Metode Kanguru Terhadap Pertumbuhan Bayi, Pengetahuan dan Sikap Ibu dalam Merawat BBLR di RSUD Cibabat. Cimahi: Stikes Jend. A. Yani Cimahi; 2010.

6. Rinto, Nindya A, Findianingsih I. Hubungan Antara Sikap, Perilaku dan Partisipasi Keluarga Terhadap Kadar Gula Darah Penderita Diabetes Melitus Tipe 2 di RS PKU Muhammadiyah. Jakarta: Fakultas Kedokteron Universitas Indonesia; 2008.

7. Health Technology Assestment Indonesia. Perawatan Bayi Berat Lahir Rendah (BBLR) dengan Metode Kanguru. Jakarta: Departemen Kesehatan RI; 2008. 
8. Winarno B. Kebijakan Publik: Teori dan Proses. Yogyakarta: MedPress (Anggota IKAPI); 2008.

9. Agustino L. Dasar-Dasar Kebijakan Publik. Bandung: CV Alfabeta; 2008.

10. Nugroho R. Public Policy Teori Kebijakan Analisis Kebijakan Proses Kebijakan Perumusan, Implementasi, Revisi Risk Management dalam Kebijakan Publik Kebijakan Sebagai The Fifth Estate Metode Penelitian Kebijakan. Jakarta: PT. Gramedia; 2008.

11. Winarno B. Kebijakan Publik: Teori, Proses, dan Studi Kasus (Edisi dan Revisi Terbaru). 1 ed. Yogyakarta: C A P S; 2012.

12. Widodo J. Analisis kebijakan Publik. Konsep dan Aplikasi Analisis Proses kebijakan Publik. Malang: Bayu Media; 2009.

13. Direktorat Jenderal Bina Pelayanan Medik Depertemen Kesehatan RI. Manajemen Bayi Berat Lahir Rendah untuk Bidan dan Perawat. Jakarta: Kementrian Kesehatan RI; 2010. 